\title{
Why Can't We Have Both? A Discussion on Work-Life Balance and Women Career Advancement in Malaysia***
}

\author{
Nursyamsyul Syifa Mustapa, Khairunneezam Mohd Noor, Mahazan Abdul Mutalib
}

Received: May 30, 2018 Revised: July 15, 2018 Accepted: July 30, 2018

\begin{abstract}
While the number of women labor force in Malaysia is increasing, only a few of them make it to the top. For many reasons, some women turn down top position offer and some of them refuse to stay working. Commitment to the family, work-life conflict and lack of support from the family and the colleagues are among issues that caused women to have less interest to pursue career advancement. This article examines the role of work-life balance and its relationship to women career advancement, and why both are important in Malaysia. The arguments are arranged based on a review of the previous literature to conceptualize the relationship between work-life balance and career advancement. It is found that both work-life balance and women career advancement are important to retain women in the working world as well as to motivate them to pursue promotion to a higher position. Even though some researchers agreed that the relationship between work-life balance and career advancement is mostly negative, others found positive relationship between both constructs. At the end of the paper, some suggestions on how to improve work-life balance and career advancement are presented as well as suggestion for future research.
\end{abstract}

Keywords: Career Advancement, Work-Life Balance, Women, Human Resource Management, Malaysia

JEL Classification Code: M50, M54.

* The authors would like to extend their gratitude to Public Service Department of Malaysia for its supports.

** The paper was presented initially at 2018 International Conference on Business and Economics (ICBE2018) and the 14th International Conference of KODISA that was held in Seoul, South Korea, June 25-27, 2018. The paper has been recognized as one of Distinguished Research Awards at ICBE2018 conference. This paper is a substantially revised and expanded version of the paper presented at ICBE2018 conference. The authors have taken into account all the comments of Editors, Session Chairs and Reviewers in the revised manuscript. The authors greatly appreciate Editors, Session Chairs and Reviewers for their valuable comments, interest in and support of this research.

1 First Author and Corresponding Author. PhD candidate, Faculty of Leadership and Management, Islamic Science University of Malaysia, Nilai, Malaysia [Postal Address: Bandar Baru Nilai, 71800 Nilai, Negeri Sembilan, Malaysia]

E-mail: syifamustapa@gmail.com

2 Senior Lecturer, Faculty of Leadership and Management, Islamic Science University of Malaysia, Nilai, Malaysia.

E-mail: neezam@usim.edu.my

\section{Introduction}

Hoobler, Lemmon and Wayne (2014) wrote that Lisa Belkin, author of the New York Times "Life's Work" column, wrote, "Why don't women run the world? Maybe it's because they don't want to". Belkin affirmed that women are less interested to be promoted to a higher position and many of them retreat from a high position. Meanwhile, Posholi (2013) and Murniati (2012) recounted in their study that women were not looking forward to a promotion because the organizations preferred men than women to be promoted to higher positions. Other factors that restrict women from getting high position are gender bias, stereotyping and discrimination against women (Al-Asfour, Tlaiss, Khan, \& Rajasekar, 2017; Orser, Riding, \& Stanley, 2012), and long working hours (International Labour Office, 2016). Women usually took a longer time to be promoted (Flynn, Earlie, \& Cross, 2015; Tlaiss \& Kauser, 2011b) and sometimes jobs that are offered to women are limited and not many

3 Associate Professor, Faculty of Leadership and Management, Islamic Science University of Malaysia, Nilai, Malaysia.

E-mail: mahazan@usim.edu.my 
opportunities for career advancement (Al-Asfour et al., 2017) due to its cultural and social tradition and not because of limitations of skills and capabilities of women (Tlaiss \& Kauser, 2011b).

Shahida, Hazelena Dewi, Mohd Hakimi and Zulhizzam (2015) found that the higher position women occupy, the higher role conflict they will experience. They also concluded that women found that role conflict is one of the biggest barriers to their career advancement. Therefore, women expected for more balance between work and life in the contemporary career setting (Greenhaus \& Kossek, 2014). However, the study on the relationship between work-life interface and career is still lacking and need more investigations (Greenhaus \& Kossek, 2014). Therefore, this article is written to examine the relationship between worklife balance and career advancement in the current career setting of Malaysia.

Women struggle to fulfil others' expectation or "respectable femininity" that influenced their career advancement perception (Ansari, 2016; Fernando \& Cohen, 2014). Respectable femininity means that women are expected to be excellent in completing works at home and at the office as well as to achieve work-life balance. Women who are capable of successfully managing work and life dimensions are regarded as having a successful career (Poon, Briscoe, Abdul-Ghani, \& Jones, 2015). Due to their commitment towards their family women desire to achieve work-life balance, unfortunately, in some careers work-life balance is not easy to accomplish.

Women's commitment to family has been considered as one of the important factors that hindering women's career advancement (Al-Asfour et al., 2017; Shah, 2014; Tlaiss \& Kauser, 2011a, 2011b). Some women in Malaysia also believed that family life is a hindrance for career advancement (Abdul Ghani Azmi et al., 2012; Tlaiss \& Kauser, 2011b) due to the cultural and social tradition of Malaysian communities that still emphasise on women's role as a nurturer in a family. The studies above are evidence that women do not always get support from the surroundings for their career advancement but always expected to fulfil certain expectations.

By understanding the relationship between women career advancement and work-life balance, issues of conflict especially pertaining work-life conflict could be addressed. This study will also increase understanding of women career advancement and work-life balance. Thus, it would also become an addition to the existing research on career advancement of women in South East Asia, particularly Malaysia.

\section{Literature Review and Discussion}

\subsection{Women Career Advancement}

A career is defined by Khadijah, Shahibudin and Ummi Naiemah (2015) as “... a fascinating and multifaceted phenomenon which is able to give an impact in various aspects of a person's life". The traditional career definition was not merely criticised because of the limitation of career to professional work life, but also because it was only focused on western middle class. A broader definition was then introduced by Super in 1976 as "The sequence of major positions occupied by a person throughout his preoccupational, occupational and postoccupational life; includes work related roles such as those of student, employee, and pensioner, together with complementary vocational, familial and civil roles". Only in the early 2000s "a more inclusive and less conceptually and culturally complex term" has been introduced; where the term 'work' was used in the area of human behaviour (Patton \& McMahon, 2014).

Career development was perceived in the 1950s as a development process that takes several years, and the process was perceived completed in early adulthood. It was only in the 1970s where a career was perceived as a lifelong process related to work activities (Patton \& McMahon, 2014). Besides career development, the career issues that usually studied among others are career choice, career success, career aspiration, career motivation as well as career advancement. Career advancement is considered as the objective aspect of success while career satisfaction is the subjective aspect of success (Shah, 2014). Career advancement refers to the status or achievements due to the activities to improve one's career. Career development, instead, refers to the process undertaken by the organisation and the employee to improve the employee's performance and job position over a specified period (Khadijah et al., 2015).

Early career advancement theories only focus on men and it is not a surprise since women were only minority in the workforce. In the 1990s and early 2000s, women were still considered as a minority in the study of career advancement, "separated from mainstream career theory" (Patton \& McMahon, 2014). Due to the difference of nature of men and women, physically, mentally, psychologically as well as different perceptions based on religious and cultural inclination, more studies should be conducted to study women career advancement. For example, commitment to family is among factors that make career choice for women is different from that of men. Furthermore, women executives follow a different path to advance in their career 
from their men counterparts and most of the time men managers advanced more in their careers (Shah, 2014).

For decades, researchers have been trying to understand the underlying issues of women career advancement. There have been debates (Farmer, 1987; Kelly \& Dabul Marin, 1998; Metz, 2017; Straub, 2007) on the issues pertaining to women career advancement. Issues like facilitation of women career advancement (Knörr, 2005), organizational supports (Burke, Koyuncu, \& Fiksenbaum, 2006) and the relationship of women career advancement and work-family conflict (Slan-Jerusalim \& Chen, 2009) have been studied. Also, women perspective on career success differs in interpretation by which some women defined their career success as advancement in their career, but others consider themselves successful by being able to manage conflict between work and life (Tlaiss, 2015).

Adogbo et al. (2015) observed in their study that women sense of responsibility towards family is the greatest barrier to their career advancement and "women are more likely to turn down positions for family-related reasons" (Allen, French, \& Poteet, 2016). Abdullah et al. (2013) concur with the idea that work-life conflict is one of the biggest barriers to women career advancement. The perception of the traditional role of women as primary caregiver has never changed and the role is observed in almost every culture existed among people. This traditional role resulted in the perception that having children could possibly increase the work-life conflict level. Cross (2010) discovered that women who have no children also perceived that having children would not enable them to achieve high positions (Metz, 2017). Mostly only single women and those women who have children older than 12 years old are considering to pursue higher positions (Cross, 2010).

Women lack the desire to pursue senior management position due to the issue of balancing between family and senior management position and women may reject more demanding careers because of a perceived role conflict (Patton \& McMahon, 2014) and heavy workloads (Murniati, 2012). Furthermore, it was found that women had to work harder than men if they want to pursue higher positions (Murniati, 2012; Shah, 2014). The most significant challenge undergone by working women today is a conflict between work and life (Adisa, Gbadamosi, \& Osabutey, 2016) and accepting a higher position usually would lead to higher conflict (Murniati, 2012). Moreover, Cross (2010) revealed that only 13 out of 30 women in her study said they are interested in pursuing a higher position. Lack of support system in the office (Posholi, 2013), as well as from the family (Itani, Sidani, \& Baalbaki, 2011) and the government (Hodges, 2017) are among barriers to women career advancement. Other barriers such as lack of mentoring facilities, gender stereotypes and social isolation that discouragingly influence their career advancement (Shah, 2014) are also the contributing factors.

Research also indicates that women's own view of their ability to exercise leadership effectively is somewhat negative (Hodges, 2017). Such feelings appear to arise despite the increasing levels of education among women (Hodges, 2017); the sense of fear because of feeling inferior as well as society's belief that women lack capabilities to be a leader. Women believed that their leadership opportunities were constrained by the view in society that women lack the capabilities for coping with the demands of leadership (Hodges, 2017). They also being discriminated in selection for promotion as well as for training and development (Hodges, 2017).

Women have been engaged in multiple strategies in order to manage work and life duties which include getting various types of support, as well as other strategies in handling career and family, such as negotiating with co-workers and spouse (Ezzedeen \& Ritchey, 2009) or other family members. Career decision-making is one of the stressful and anxiety-provoking life experience which could lead to career decision-making difficulties (Bullock-Yowell et al., 2015). Women must think through all aspects in making a career decision, especially their family when considering for an advancement in career. Therefore, women need more support such as organisational and managerial support (Rowley, Kang, \& Lim, 2016) as well as family support (Kemp \& Zhao, 2016) to ensure that every aspect of work and life is continue to be in order or manageable when they decide to accept a promotion.

\subsection{Women Career Advancement Issues in Malaysia}

Malaysian population consists of more than 32 million people and 48 percent of the population are women (Bernama, 2017). 14 million of the total population of Malaysian are employed and 38 percent of them are women. Traditionally, women were viewed as a homemaker and they were not exposed to the working world even though Hirschman (2016) sustained that Malaysian women participation in economics were very active since the 1960s. Most of the women in Malaysia work for improving economies of their family (Itani et al., 2011). Between 1995 and 2000 women participation in economies was very low, and they were mostly participated in the middle and lowlevel jobs, with the majority of them was concentrated in the unskilled/semi-skilled categories and recruited as a low wage labour force (Aminudin \& Abdullah, 2009). Therefore, the Malaysian government has given continuous effort in promoting women's equality in career advancement (Talentcorp Malaysia \& ACCA, 2013). With the outpouring of women labour today, the traditional role of women as full- 
time housewives has changed dramatically and with the increase of women participation in economics, the issue of career advancement must be given more attention today, more than it was before.

$60 \%$ of working women in Malaysia agreed that they have an equal opportunity to men in career progression (Talentcorp Malaysia \& ACCA, 2013). Department of Statistics of Malaysia (2015) reported that $56.2 \%$ of professionals in Malaysia are women but only $22.5 \%$ of women are promoted to the managerial position. In 2015, the former Prime Minister of Malaysia, Datuk Seri Mohd Najib bin Tun Abdul Razak remarked that only $16 \%$ of Malaysian women are on the boards of public companies and the number of women on listed boards is even smaller at $10.3 \%$. The government's targeted for at least $30 \%$ women participation in boards of public companies (de Pater, 2015). Therefore, he asked for more assistance to be given to women to help them to break the glass ceiling. Also, the former Chief Secretary of Malaysian Government, Tan Sri Dr. Ali Hamsa announced that $57.5 \%$ of civil service in Malaysia are occupied by women (this percentage excludes police and military service) with $35 \%$ of the top management posts are occupied by women (Ministry of Women Family and Community, 2016). The report shows that despite the effort taken by the government to promote more women into top posts (International Labour Office, 2016; Noor \& Mahudin, 2016), the number is still low.

Therefore, it is not a surprise when Global Gender Gap reported that Malaysia is ranked at number 106 (out of 144 countries) in terms of gender gaps on economic, education, health and political criteria (World Economic Forum, 2016) compared to 2011 whereby Malaysia was listed at number $98^{\text {th }}$. This means that Malaysia's gender gap is widening despite its effort to promote more women involvement in those sectors. Malaysia is ranked at number 12 out of 16 countries listed in the report under East Asia and the Pacific region. Therefore, this study is important to investigate women career advancement, to help to close the gender gap in Malaysia. While many types of research were conducted all over the world on women career advancement, most studies were conducted in America and Europe, leaving spaces for studies on women career advancement in Asia (Murniati, 2012; Tlaiss \& Kauser, 2011b), particularly Malaysia.

Malaysian society is a collectivist society (Ibrahim, 2015; Sumaco, Imrie, \& Hussain, 2014) and loyalty in a collectivist culture is vital. Therefore, Malaysians appreciate time with family which is why it also effect the career advancement of women. Malaysian is seen as having a need to be with family and give importance to family and extended family (Ibrahim, 2015; Sumaco et al., 2014). The collectivist society of Malaysia has shaped the culture in Malaysia where
Malaysians give more importance to family members than career and this will influence the career decision-making of women. Therefore, work-life balance and family issues are important aspects for women career advancement (Subramaniam, Mohamed Khadri, Maniam, \& Ali, 2016) whereby $42 \%$ women agreed that both are their biggest challenge. Women are also expected to do most of the household work even though they are working full-time (Fernandez \& Shiang, 2017; Hirschman, 2016).

\subsection{Work-Life Balance}

The most widely used definition of work-life balance is a lack of conflict or interference between work and family/life roles (Frone, 2003). Therefore, many studies focus on the absence of conflict between work and personal life as a component of work-life balance due to this definition. Another component of work-life balance is work-life enrichment or facilitation.

Balance is a more global view than the conflict and enrichment experiences (Carlson et al., 2009). Conflict and enrichment seem to happen on an individual level and are believed to be linking mechanisms between work and family (Marks \& Macdermid, 1996). These mechanisms specify the extent to which they will affect work and family either negatively (conflict) or positively (enrichment) (Carlson et al., 2009). This approach was confirmed by Carlson et al. (2009) suggesting that in their study, balance explained more variance beyond conflict and enrichment for five work and family outcomes they tested, showing that balance is theoretically different from conflict and enrichment (Shah, 2014). The negative side of work-life is operationalised as work-life conflict and the positive side is operationalised as enrichment or facilitation. A negative relation between work and family are seen as conflict can influence an individual's emotional and physical health leading to detrimental effects on organizations such as absenteeism and declining productivity (Shah, 2014). According to Netemeyer, Boles and Mcmurrian (1996), work-life conflict is "...distinct but related forms of inter-role conflict". Work-life conflict and work-life balance are also closely related concepts and they are conceptually overlapping because these concepts are defined or imply the absence of the other (Kossek \& Lee, 2017).

This study focusses on the work-life conflict component to investigate the work-life balance. Greenhaus and Beutell (1985) defined work-life conflict as "a form of inter-role conflict in which the role pressures from the work and family domains are mutually incompatible in some respect." Worklife conflict is hypothesised as a concept with bidirectional nature (work-to-life and life-to-work) (Mcmillan, 2011), multiple forms (time-based, strain-based, and behavior- 
based) (Greenhaus \& Beutell, 1985; Slan-Jerusalim \& Chen, 2009) and multiple life roles (e.g., spouse, parental, elder care, home care, and leisure).

Work-life conflict concept was initially explained in the 1960 s by the role theory framework. The role theory predicts that inter-role conflict from work and family are mutually mismatched. Responsibilities of a person do not only lie in his work but also on his family. At the workplace, a conflict between responsibility towards work and family may exist. However, it is not possible, argued by Murphy and Doherty (2011), to measure work-life balance or work-life conflict in an absolute way because of it is perceived based on personal circumstances. The conflict, nevertheless, can be resolved, and among them are through getting social support (Achour, Grine, \& Mohd. Nor, 2014) and using religious coping strategies (Achour et al., 2014; Sav, Harris, \& Sebar, 2014). Work-life balance issues have become a major attention in research and practices since 1980, due to increasing number of women employees. "Increasing female workforce participation, higher divorce rates, more dualearner and single-parent families, more families with both child and elder care responsibilities, and a reconceptualization of traditional gender roles...increased globalization and use of technology, knowledge-based economies, deregulations, and labour shortages" are also among other reasons of the increased attention on the study of work-life balance (Slan-Jerusalim \& Chen, 2009).

Single people and those without children also reported having some conflict between work and personal life as all the individuals may be sons, daughters, sisters, brothers, or may live with friends who function as a family (Kossek \& Lee 2017; Waumsley, Houston, \& Marks, 2010). Work-life balance is believed to have an important impact towards their organisations as well as employees (Mohd. Noor, 2011). Hence, the Ministry of Women, Family, and Community Development has collaborated with TalentCorp Malaysia in creating a website to feature the guidelines and importance of work-life practices in Malaysia. This effort shows that the government has put effort into increasing the quality of work-life (Talentcorp Malaysia \& ACCA, 2013). Nevertheless, (Azlinzuraini Ahmad et al., 2014) argued that work-life policies awareness is still low in Malaysia despite the government initiatives on it. "In Malaysia, the problem of work-family balance and family obligations is a critical matter" (Achour et al., 2014) and further study on work-life balance could increase more understanding on balancing between work and personal life matters. In this study, the terms "work-life conflict" will be occasionally used to illustrate the elevation of work-life balance by reducing worklife conflict.

\subsection{Work-life Balance among Gender}

Women are more likely to spend more working hours than men and this could be caused by the larger share of household work that is generally borne by women. Long working hours in Malaysia (International Labour Office, 2016) could also decrease the level of work-life balance. This creates a desire for less hours of work, however, fewer working hours is perceived as low job commitment (Fernandez \& Shiang, 2017) and thus means difficulties in getting promotion.

According to Abdul Ghani Azmi, Syed Ismail, and Basir (2011), women put their family as a priority, which created conflict when women need to work. Yavas, Babakus, and Karatepe (2008) claimed that female frontline employees in their study experience significantly higher levels of workfamily and family-work conflicts than their male counterparts. Sav and Harris (2013) however, found that there is no evidence that work-life balance experience is different between men and women.

On the contrary, Belwal and Belwal (2014) maintained work-life balance issues affect women the most and had become a barrier to women career advancement. Many studies found that work-to-family conflict is higher than family-to-work conflict (Zhang, Foley, \& Yang, 2013). Conflicts in the work-life balance of working women affect their health who report more stress, headache, muscle tension, weight gain and depressed than their male counterparts, according to Delina and Raya (2013). Itani et al. (2011) indicated it is not possible for women to have work and life balance; they only increase stress by pretending to have the balance.

\subsection{The Relationship between Work-Life Balance and Career Advancement}

It is eminent that the level of work-life conflict differs from each individual, but it does affect career advancement distinctively. It is found from a study that employees with children and/or elderly dependents are more likely to have higher work and life conflict. The majority (85\%) of women who wanted higher positions were either single or have no children or have children older than 12 years of age (Cross, 2010), which suggest that women perceived having children as a barrier to career advancement. Further, Sav and Harris (2013) argued non-work related antecedents have more impacts on life-work conflict among women than in men, which explains the high level of conflict among women. Moreover, employees with a higher level of education find it harder to balance between work and personal life than employees with a lower level of education (Aminah Ahmad, 2008). In other words, employees with higher education 
level experienced higher work-life conflict than those with lower education level.

There is, however, a significant positive relationship between work-life balance and career advancement potential (Lyness \& Judiesch, 2008, 2014). Consequently, they argued that managers who were rated higher on worklife balance were rated higher on career advancement potential than the managers who were rated lower on worklife balance. Lyness and Judiesch (2014) discovered that there was a positive relationship between perceived worklife balance and career advancement motivation based on self, peer, and supervisor ratings. In addition, Marican et al. (2011) implied that there are positive effects of work on families such as lesser depression and positive psychological well-being. Employees who attain a balanced life and career usually have better performance compared to those who don't (Omar, Mohd, \& Ariffin, 2015). With these contradictory findings from previous research, the researcher decided to investigate whether the work-life balance will have a positive or negative effect on women career advancement.

Flynn et al. (2015) informed that most of the respondents from their study negated the idea of the existence of gender inequality in their organization, however, the result shows otherwise. For example, the issue of visibility of women may negatively affect their opportunity to reach a higher position. Women were always had to take leave (i.e. maternity leave or taking leave to take care of children) which is not the case for men. Cross (2010) supported the argument by saying that if women are not visible to the eyes of the top management team, they are less likely to get promoted.

Careers can be understood better by studying the influence of work and life on them, in past research, it was confirmed that work-life interface has a significant relationship with career advancement (Greenhaus \& Kossek 2014; Saadin et al., 2016). Further, Linge (2015) found that family responsibilities and married status both have a significant relationship with the career advancement of women to managerial positions.

One of the biggest challenges of every woman is managing career with family (Beal, 2017). Some people believed that when a woman is not at home, her family suffers (Itani et al., 2011). Itani et al. (2011) insisted that women should set the right priorities, in terms of what they really wanted. If they want to raise the children, the idea of having a career should be postponed or withheld. However, if they want a career they must accept the reality that they would not have total care and control of their own children and have to let the children into the care of the other caretaker. With all those perspectives in mind, consequently, some women perceived themselves to be successful if they are able to manage both work and family with less conflict (Tlaiss, 2015).

Work-life conflict leads to lack of job tenure, which makes it difficult for promotions and hence careers. Successfully coping with work-life conflict is critical to careers because many females leave work due to childbirth and childcare. If this issue can be resolved, there is hope for women's advancement to high-ranking positions. (Rowley et al., 2016).

\section{Conclusion}

For some women, a higher pay may not be a motivation to pursue high positions. Career success for them, may not be the highest position they might achieve in an organization. They perceived being able to balance between work and home as a definition of success. Even though many researches support the negative relationship between work-life balance and career advancement, there is other research that found the relationship to be positive. These contradicting findings should be examined further for reasons that could contribute to the different outcomes.

Sometimes, a good policy is not enough to retain women in labour market, for example, women choose to drop out of the labour market despite laws that entitle national women to 70 days of maternity leave with optional leave for up to two years on a reduced salary to enable mothers to nurse infant children (Itani et al., 2011). When the conflict between work and life become higher and unmanageable, women would highly consider sacrificing career over family (Itani et al., 2011). Others maintain that the difficulty of balancing professional and family obligations leads to women feeling that they are unable to take on a leadership role. The conflict between home and work roles leads to women feeling frustrated, inferior, and lack of self-confidence (Hodges, 2017). In Africa and Nigeria, for example, any woman who intends to work or involve into business must get approval from the government or leadership to ensure that she is able to adequately combine her responsibilities as a wife and mother with that of a professional effectively; otherwise, she will have to struggle with social disapproval (Beal, 2017). Therefore, by promoting work-life balance could be the answer to encourage more women to retain and advance in their career.

Both work-life balance and career advancement can be pursued with a good social support. It was found that having a supportive supervisor may be equivalent to having a supportive spouse that could assist women in balancing work and family issues (Borhanuddin, 2009). Russo et al. (2015) argued, "...work and family social support is key resources that can promote greater role balance, higher 
readiness to engage in multiple roles and unleash positive energy." Married women who get helps from their husband were found to be happier and have a more successful career (Borhanuddin, 2009). Therefore, a support from the people around women could be one of the answers that enable women to achieve both work-life balance and career advancement.

\section{References}

Abdul Ghani Azmi, I., Syed Ismail, S. H., \& Basir, S. A. (2011). Career Advancement Barriers in Malaysian Federal Public Service. In 2011 International Conference on Financial Management and Economics. IPEDR vol.11 (2011). Singapore: IACSIT Press, (pp. 324-328). Retrieved July 14, 2017, from http://www.ipedr.com/vol11/62-W10019.pdf.

Abdul Ghani Azmi, I., Syed Ismail, S. H., \& Basir, S. A. (2012). Women Career Advancement in Public Service: A Study in Indonesia. Procedia - Social and Behavioral Sciences, 58, 298-306. doi:10.1016/j.sbspro.2012.09.1004

Abdullah, N. Z., Arshad, R. A., \& Ariffin, M. H. (2013). Technical Female Graduates in The Malaysian Construction Industry: Attrition Issues. International Surveying Research Journal, 3(1), 33-43. doi:10.1061/41138(386)75

Achour, M., Grine, F., \& Mohd. Nor, M. R. (2014). Work family conflict and coping strategies : Qualitative study of Muslim female academicians in Malaysia. Mental Health, Religion \& Culture, 17(10), 10021014.

Adisa, T. A., Gbadamosi, G., \& Osabutey, E. L. C. (2016). Work-family balance: A case analysis of coping strategies adopted by Nigerian and British working mothers. Gender in Management: An International Journal, 31(7), 414 - 433. doi:10.1108/GM-012016-0010

Adogbo, K. J., Ibrahim, A. D., \& Ibrahim, Y. M. (2015). Development of a Framework for Attracting and Retaining Women in Construction Practice. Journal of Construction in Developing Countries, 20(1), 99115.

Ahmad, A. (2008). Job, Family and Individual Factors as Predictors of Work-Family Conflict. Journal of Human Resource and Adult Learning, 4(1), 57-65.

Ahmad, A., Omar, K., Mohd. Salleh, A. M., Abdul Aziz, N. D., Shaw, N. E., \& Bown, N. J. (2014). Assessing Flexible Working Policies in Terengganu: A Theoretical Framework of Work-Home Interaction. International Journal of Business, Economics and
Law, 5(2), 1-9.

Al-Asfour, A., Tlaiss, H., Khan, S. A., \& Rajasekar, J. (2017). Saudi women's work challenges and barriers to career advancement. Career Development International, 22(02), 184-199. doi: 10.1108/CDI-11-2016-0200

Allen, T. D., French, K. A., \& Poteet, M. L. (2016). Women and career advancement : Issues and opportunities. Organizational Dynamics, 45, 206-216. doi:10.1016/j.orgdyn.2016.07.006

Aminudin, N., \& Abdullah, N. A. (2009). Gender Differences in Career Advancement: a Preliminary Study in R\&D Organization in Malaysia. In Persidangan Kebangsaan Ekonomi Malaysia (PERKEM IV). Vol. 2. (pp. 421-426). Memacu Pembangunan Ekonomi Dalam Ketidaktentuan Persekitaran Global. Kuantan, Pahang, Malaysia. 2-4 Jun 2009. Retrieved July 14, 2017, from http://www.ukm.my/fep/perkem/pdf/ perkemIV/PERKEM2009-2-33.pdf

Ansari, N. (2016). Respectable femininity: a significant panel of glass ceiling for career women. Gender in Management An International Journal, 31(8), 528541. doi:10.1108/GM-03-2015-0012

Beal, B. (2017). Home truths for women leaders: Nigerian bosses identified by domestic role. Human Resource Management International Digest Human Resource, 25(2), 10-12. doi:10.1108/HRMID-01-2017-0008

Belwal, S., \& Belwal, R. (2014). Work-life balance, familyfriendly policies and quality of work life issues: Studying employers' perspectives of working women in Oman. Journal of International Women's Studies, 15(1), 96-117.

Bernama. (2017). Malaysia's population reaches 32 million ; males still outnumber females. The New Straits Times. Retrieved July 14, 2017, from https://www.nst.com.my/news/nation

Borhanuddin, A. (2009). The Challenges and Implication of Dual Carrier Women on Future Work Force in Malaysia : A Global Perspective. Paper presented in: International Conference on Malaysia: Malaysia in Global Perspective. Cairo University, Egypt.

Bullock-Yowell, E., Reed, C. A., Mohn, R. S., Galles, J., Peterson, G. W., \& Reardon, R. C. (2015). Neuroticism, Negative Thinking, and Coping with Respect to Career Decision State. Career Development Quarterly, 63(4), 333-347. doi:10.1002/cdq.12032

Burke, R. J., Koyuncu, M., \& Fiksenbaum, L. (2006). Organisational practices supporting women's career advancement and their satisfaction and well-being in Turkey. Women In Management Review, 21(8), 610 624. doi:10.1108/09649420610712018 
Cross, C. (2010). Barriers to the executive suite: evidence from Ireland. Leadership \& Organization Development Journal, 31(2), 104-119. doi:10.1108/01437731011024376

de Pater, I. E. (2015, November 13). Overcoming gender bias in career advancement. The New Straits Times. Retrieved July 14, 2017, from https://www.nst.com.my

Delina, G., \& Raya, R. P. (2013). A study on Work-Life Balance in Working Women. IRACST - International Journal of Commerce, Business and Management, 2(5), 274-282.

Ezzedeen, S. R., \& Ritchey, K. G. (2009). Career advancement and family balance strategies of executive women. Gender in Management : An International Journal, 24(6), 388-411. doi:10.1108/17542410910980388

Farmer, H. S. (1987). A Multivariate Model for Explaining Gender Differences in Career and Achievement Motivation. Educational Researcher, 16(2), 5-9. doi:10.3102/0013189X016002005

Fernandez, J. L., \& Shiang, L. E. (2017). Overemployment of Workers in Penang, Malaysia: An Empirical Analysis. The Journal of Asian Finance, Economics and Business, 4(4), 17-26. doi:10.13106/jafeb.2017.vol4.no4.17

Fernando, W. D. A., \& Cohen, L. (2014). Respectable Femininity and Career Agency: Exploring Paradoxical Imperatives. Gender, Work and Organization, 21(2), 149-164. doi:10.1111/gwao.12027

Flynn, A., Earlie, E. K., \& Cross, C. (2015). Gender equality in the accounting profession: one size fits all. Gender in Management: An International Journal, 30(6), 479-499. doi:10.1108/GM-06-2015-0048

Frone, M. R. (2003). Work-Family Balance. In J. C. Quick \& L. E. Tetrick (Eds.), Handbook of Occupational Health Psychology (pp. 143-162). Washington D. C.: American Psychological Association. doi:10.1016/B978-012373947-6.00694-2

Greenhaus, J. H., \& Beutell, N. J. (1985). Sources of and Conflict Family Between Work and family roles. The Academy of Management Review, 10(1), 76-88. doi:10.5465/AMR.1985.4277352

Greenhaus, J. H., \& Kossek, E. E. (2014). The Contemporary Career: A Work-Home Perspective. Annual Review of Organizational Psychology and Organizational Behavior, 1, 361-388. doi:10.1146/annurev-orgpsych-031413-091324

Hirschman, C. (2016). Gender, the Status of Women, and Family Structure in Malaysia. Malaysian Journal of Economic Studies, 53(1), 33-50.
Hodges, J. (2017). Cracking the walls of leadership: women in Saudi Arabia. Gender in Management: An International Journal, 32(1), 34-46. doi:10.1108/GM11-2015-0106

Hoobler, J. M., Lemmon, G., \& Wayne, S. J. (2014). Women's Managerial Aspirations: An Organizational Development Perspective. Journal of Management, 40(3), 703-730. doi:10.1177/0149206311426911

Ibrahim, D. (2015). An overview of the state influences on workers' work-life integration in Malaysia. IJASOSInternational E-Journal of Advances in Social Sciences, 1(2), 163. doi:10.18769/ijasos.51674

International Labour Office. (2016). Women at Work: Trends 2016 (Vol. 42). Geneva. Retreived July 14, 2017, from http://www.ilo.org

Itani, H., Sidani, Y. M., \& Baalbaki, I. (2011). United Arab Emirates female entrepreneurs: motivations and frustrations. Equality, Diversity and Inclusion: $A n$ International Journal, 30(5), 409-424. doi:10.1108/02610151111150654

Kelly, R. M., \& Dabul Marin, A. J. (1998). Position power and women's career advancement. Women in Management Review, 13(2), 53-66. doi:10.1108/09649429810208738

Kemp, L. J., \& Zhao, F. (2016). Influences of cultural orientations on Emirati women's careers Influences of cultural orientations on Emirati women's careers. Personnel Review, 45(5), 988-1009. doi:10.1108/PR-08-2014-0187

Khadijah, N., Shahibudin, I., \& Ummi Naiemah, S. (2015). Developing a Conceptual Framework for Measuring Women Career Advancement. In Conference on Business Management Research II (CBMR II 2015). School of Business Management, Universiti Utara Malaysia, Kedah, Malaysia, 22 December 2015 (pp. 141-153). Retrieved July 14, 2017, from http://www.cbmsbm.com/uploads/1/9/8/7/19870781/h r2.pdf.

Knörr, H. (2005). Factors that Contribute to Women's Career Development in Organizations: A Review of the Literature. ERIC Number: ED492334 (pp. 38-45). Retrieved July 14, 2017, from https://eric.ed.gov/?id=ED492334.

Kossek, E. E., \& Lee, K. (2017). Work-family conflict and work-life conflict. Oxford Research Encyclopedia of Business and Management, 1-25. doi:10.1093/acrefore/9780190224851.013.52

Linge, T. K. K. (2015). Social-Family Issues as Barriers to Career Advancement : The Perception of Women Employees in Kenya. International Journal of Business and Social Research, 5(4), 52-57.

Lyness, K. S., \& Judiesch, M. K. (2008). Can a Manager 
Have a Life and a Career ? International and Multisource Perspectives on Work - Life Balance and Career Advancement Potential. Journal of Applied Psychology, 93(4), 789-805. doi:10.1037/0021-9010.93.4.789

Lyness, K. S., \& Judiesch, M. K. (2014). Gender egalitarianism and work-life balance for managers: Multisource perspectives in 36 countries. Applied Psychology, 63(1), 96-129. doi:10.1111/apps.12011

Mansor, S., Fatahul Ariffin, H. D., Md Baharudin, M. H., \& Hamzah, Z. (2015). The relationship between role conflict as internal barrier and career advancement among women in banking sector. In First International Conference on Economics and Banking (pp. 260-264). Atlantis Press. Retrieved July 14, 2017, from https://www.atlantispress.com/proceedings/iceb-15

Marican, S., Sabil, S., Zakaria, R. H., \& Rahman, A. A. (2011). Can supportive management contribute to the well being of Muslim working women in Malaysia ? African Journal of Business Management, 5(12), 4883-4890. doi:10.5897/AJBM10.1352

Mcmillan, H. S. (2011). Examining the Relationship between Work / Life Conflict and Life Satisfaction in Executives : The Role of Problem-Focused Coping Techniques. Doctoral dissertation, University of Tennessee. Retreived from http://trace.tennessee.edu/utk_graddiss/1000

Metz, I. (2017). Advancing the careers of women with children. Career Development International, 10(3), 228-245. doi:10.1108/13620430510598346

Ministry of Women Family and Community. (2016). Statistics on Women, Family and Community: Malaysia 2016. Retrieved July 14, 2017, from https://www.kpwkm.gov.my/kpwkm/uploads/files/Pen erbitan/Buku Perangkaan/Perangkaan 2016.pdf

Mohd. Noor, K. (2011). Work-Life balance and intention to leave among academics in Malaysian public higher education institutions. International Journal of Business and Social Science, 2(11), 240-248. Retrieved from http://ijbssnet.com/journals/ Vol._2_No._11_[Special_Issue-June_2011]/34.pdf

Murniati, C. T. (2012). Career advancement of women senior academic administrators in Indonesia: supports and challenges. Doctoral dissertation, University of lowa. Retrieved from http://ir.uiowa.edu/etd/3358

Murphy, F., \& Doherty, L. (2011). Equality, Diversity and Inclusion: An International Journal The experience of work life balance for Irish senior managers The experience of work life balance for Irish senior managers. Equality, Diversity and Inclusion: An International Journal, 30(4), 252-277. doi:10.1108/02610151111135732

Netemeyer, R. G., Boles, J. S., \& Mcmurrian, R. (1996). Development and Validation of Work-Family Conflict and Family-Work Conflict Scales. Journal of Applied Psychology, 81(4), 400-410.

Noor, N. M., \& Mahudin, N. D. M. (2016). Work, family and women's well- being in Malaysia. In M. L. Connerly \& J. Wu (Eds.), Handbook on Well-Being of Working Women (pp. 717-734). New York: Springer Science + Business Media Dordrecht. doi:10.1007/978-94-017-9897-6 40

Omar, M. K., Mohd, I. H., \& Ariffin, M. S. (2015). Workload, role conflict and work-life balance among employees of an enforcement agency in Malaysia. International Journal of Business, Economics and Law, 8(2), 5257.

Orser, B., Riding, A., \& Stanley, J. (2012). Perceived career challenges and response strategies of women in the advanced technology sector. Entrepreneurship \& Regional Development, 24(1-2), 73-93.

Patton, W., \& McMahon, M. (2014). Career Development and Systems Theory. A. Collin, K. Maree, P. Mcllveen, V. Skorikov, and R. van Esbroeck (Eds.) (3rd. ed.). Rotterdam: Sense Publishers. doi:10.1007/978-94-6209-635-6

Poon, J. M. L., Briscoe, J. P., Abdul-Ghani, R., \& Jones, E. A. (2015). Meaning and determinants of career success: A Malaysian perspective. Revista de Psicologia Del Trabajo y de Las Organizaciones, 31(1), 21-29. doi:10.1016/j.rpto.2015.02.002

Posholi, M. R. (2013). An examination of factors affecting career advancement of women into senior positions in selected parastatals in Lesotho. African Journal of Business Management, 7(35), 3343-3357. doi:10.5897/AJBM12.521

Rowley, C., Kang, H. R., \& Lim, H. J. (2016). Female manager career success: The importance of individual and organizational factors in South Korea. Asia Pacific Journal of Human Resources, 54(1), 98122. doi:10.1111/1744-7941.12071

Russo, M., Shteigman, A., \& Carmeli, A. (2015). Workplace and family support and work - life balance : Implications for individual psychological availability and energy at work. The Journal of Positive Psychology, 11(2), 173-188. doi:10.1080/17439760.2015.1025424

Saadin, I., Ramli, K., Johari, H., \& Harin, N. A. (2016). Women and Barriers for Upward Career Advancement - A Survey at Perak State Secretariat, Ipoh, Perak. Procedia - Social and Behavioral 
Sciences, $\quad 35, \quad 574-581 . \quad$ doi:10.1016/S2212$5671(16) 00070-8$

Sav, A., \& Harris, N. (2013). Work-life conflict in Australian Muslims: is gender important? Gender in Management: An International Journal, 28(8), 486504. doi:10.1108/GM-01-2013-0013

Sav, A., Harris, N., \& Sebar, B. (2014). Australian Muslim men balancing work, family and religion: a positive look at a negative issue. Personnel Review, 43(1), 2-18. doi:10.1108/PR-07-2012-0130

Shah, S. S. (2014). The role of work-family enrichment in work-life balance \& career success: a comparison of German \& Indian managers (Doctoral dissertation). Ludwig-Maximilians-Universität. Retrieved July 14, 2017, from http://edoc.ub.uni-muenchen.de/16634/

Slan-Jerusalim, R., \& Chen, C. P. (2009). Work-Family Conflict and Career Development Theories: A Search for Helping Strategies. Journal of Counseling and Development : JCD, 87(4), 492-500. doi:10.1002/j.1556-6678.2009.tb00134.x

Straub, C. (2007). A comparative analysis of the use of work-life balance practices in Europe Do practices enhance females' career advancement? Women in Management Review, 22(4), 289-304. doi:10.1108/09649420710754246

Subramaniam, G., Mohamed Khadri, N. A., Maniam, B., \& Ali, E. (2016). The Glass Ceiling Phenomenon- Does it really affect women's career advancement in Malaysia? Journal of Organizational Culture, Communications and Conflict, 10(1), 81-89. doi:10.1016/j.sbspro.2015.01.350

Sumaco, F. T., Imrie, B. C., \& Hussain, K. (2014). The Consequence of Malaysian National Culture Values on Hotel Branding. Procedia - Social and Behavioral Sciences, $\quad 144, \quad 91-101$. doi:10.1016/j.sbspro.2014.07.277
Talentcorp Malaysia, \& ACCA. (2013). Retaining Women in the Workforce - 50 Champions of Gender Diversity. Kuala Lumpur. Retrieved from https://www.talentcorp.com.my

Tlaiss, H. (2015). Neither-nor: career success of women in an Arab Middle Eastern context. Employee Relations, 37(5), 525-546.

Tlaiss, H., \& Kauser, S. (2011a). Career success of Arab women managers: an empirical study in Lebanon. Education, Business and Society: Contemporary Middle Eastern Issues, 4(1), 43-61. doi:10.1108/17537981111111265

Tlaiss, H., \& Kauser, S. (2011b). The impact of gender, family, and work on the career advancement of Lebanese women managers. Gender in Management: An International Journal, 26(1), 8-36.

Waumsley, J. A., Houston, D. M., \& Marks, G. (2010). What about Us ? Measuring the Work-Life Balance of People Who Do Not Have Children. Review of European Studies, 2(2), 3-18.

World Economic Forum. (2016). The Global Gender Gap Report 2016. Geneva, Switzerland : World Economic Forum. doi:10.1177/0192513X04267098

Yavas, U., Babakus, E., \& Karatepe, O. M. (2008). Attitudinal and behavioral consequences of workfamily conflict and family-work conflict: Does gender matter? International Journal of Service Industry Management, $\quad 19(4), \quad 7-31$. doi:10.1108/09564230810855699

Zhang, M., Foley, S., \& Yang, B. (2013). Work-family conflict among Chinese married couples: testing spillover and crossover effects. The International Journal of Human Resource Management, 24(17), 3213-3231. doi:10.1080/09585192.2013.763849 